\title{
The Contribution of Integrated Marine Policies to Marine Environmental Protection: The Case of Norway
}

Lena Schфning,

UIT Norwegian Centre for the Law of the Sea, Faculty of Law, UIT The Arctic University of Norway, Troms $\emptyset$, Norway

lena.schoning@uit.no

\begin{abstract}
This article investigates the contribution of the Norwegian integrated marine management (IMM) plans to marine environmental protection and conservation. These plans have been described as international best practice, and the government's goal is 'for Norway to be a pioneer in developing an integrated ecosystem-based management regime for marine areas'. The plans pursue other objectives, including sustainable use and value creation, but this article focuses on their contribution to environmental objectives. By means of a problem analysis, the article outlines three approaches to 'marine environmental protection and conservation' that contribute thereto in profoundly different ways. The contribution of the IMM plans to each of these approaches is examined, leading to the conclusion that two are embedded in the plans, which therefore primarily contribute to some reduced harm, as opposed to contributing to longterm marine environmental protection. This suggests that integrated marine plans and policies are relevant for more restricted environmental objectives.
\end{abstract}

\section{Keywords}

marine spatial planning - marine ecosystem governance - integrated ocean management environmental management 


\section{Introduction ${ }^{1}$}

The Norwegian integrated management plans for the marine environment (IMM plans) ${ }^{2}$ have been described as best practice, ${ }^{3}$ and the government's goal is 'for Norway to be a pioneer in developing an integrated ecosystem-based management regime for marine areas' ${ }^{4}$ This article critically investigates the plans' contribution to marine environmental protection and conservation. Although the plans also pursue objectives other than marine environmental protection and conservation, such as sustainable use and value creation, the analysis here focuses on their contribution to the environmental objective.

The national integrated marine plan (or policy) ${ }^{5}$ is framed within a broader ecological and international governance context. The hypothesis, which is scrutinized in the problem framing section, is that not all environmental problems or challenges can be addressed within the framework of a national integrated marine management policy. Thus, three environmental

\footnotetext{
${ }^{1}$ This research was financed by the KG Jebsen Foundation and UiT The Arctic University of Norway. The author thanks the anonymous reviewers and editor for highly appreciated feedback and all my friendly colleagues for discussions and comments on earlier drafts. The responsibility for errors of fact or judgement remains with the author.

${ }^{2}$ Government of Norway, Ministry of Climate and Environment, Helhetlige Forvaltningsplaner for de Norske Havområdene [Integrated Management Plans for the Norwegian Marine Areas], Report No. 20 to the Storting (2019-2020) (in Norwegian) [Norwegian IMM Plans] (also referred to as the 'most recent IMM plans' in this article) available at https://www.regjeringen.no/no/dokumenter/meld.-st.-20-20192020/id2699370/?ch=1. All websites accessed on 24 August 2020 unless otherwise mentioned. The management regime set out in the plans was first launched in the white paper Protecting the Riches of the Seas, Report No. 12 to the Storting (2001-2002), available at https://www.regjeringen.no/en/dokumenter/report-no.-12-to-the-storting-2001-2002/id195387/. The Norwegian government originally adopted three integrated marine management plans, reflecting a spatial division of the ocean into three areas. These are (1) Integrated Management of the Marine Environment of the Barents Sea and the Sea Areas off the Lofoten Islands, Report No. 8 to the Storting (2005-2006) available at https://www.regjeringen.no/en/dokumenter/Report-No-8-to-the-Storting-
}

20052006/id456957/?q=Integrated\%20management\%20Barents [Barents Sea IMM Plan]; (2) Integrated Management of the Marine Environment of the Norwegian Sea, Report No. 37 to the Storting (2008-2009) available at https://www.regjeringen.no/en/dokumenter/report-no.-37-to-the-storting-2008-2009/id560159/ [Norwegian Sea IMM Plan]; and (3) Integrated Management of the Marine Environment of the North Sea and Skagerrak (Management Plan), Report to the Storting No. 37 (2012-2013) available at https://www.regjeringen.no/en/dokumenter/meld.-st.-37-2012-2013/id724746/ [North Sea IMM Plan]. Prior to the most recent IMM plans, the plans for the Barents Sea (twice) and Norwegian Sea were updated: First Update of the Integrated Management Plan for the Marine Environment of the Barents Sea-Lofoten Area, Report No. 10 to the Storting (2010-2011) available at https://www.regjeringen.no/en/dokumenter/meld.-st.-1020102011/id635591/; Update of the Integrated Management Plan for the Barents Sea-Lofoten Area Including an Update of the Delimitation of the Marginal Ice Zone, Report to the Storting No. 20 (2014-2015) available at https://www.regjeringen.no/en/dokumenter/meld.-st.-20-20142015/id2408321/; and Update of the Integrated Management Plan for the Norwegian Sea, Report No. 35 to the Storting (2016-2017)'(Update of the integrated management plan for the Norwegian Sea) available at https://www.regjeringen.no/en/dokumenter/meld.-st.-3520162017/id2547988/ [Norwegian Sea IMM Update]. The official versions of these documents are in Norwegian, but English translations exist, as concerns all plans but the most recent document (Norwegian IMM Plans). This article will refer to the English versions and the pagination of the English versions except for the most recent IMM plans, which refers to the Norwegian version and pagination.

${ }^{3}$ CN Ehler, 'Pan-Arctic marine spatial planning: An Idea whose time has come,' in E Tedsen, S Cavalieri, and RA Kraemer (eds), Arctic Marine Governance: Opportunities for Transatlantic Cooperation (Springer, Berlin, 2014) 199-213, abstract; a H Hoel, 'Integrated Oceans Management in the Arctic: Norway and beyond' (2010) 1(2) Arctic Review on Law and Politics 186-206, at p. 188.

${ }^{4}$ North Sea IMM Plan (n 2), at p. 13.

${ }^{5}$ The IMM plans, although referred to as plans, bear strong characteristics of policy by including description of goals, extensive descriptions of activities and ecosystems, and briefly and generally referring to the measures (which are elaborated on or concretised in other relevant documents). The terms policy and plan overlap to some extent, which is why both terms are used here, with plan referring to one of the plans, and policy when the plans are discussed as an example of a national instrument for integrated marine management. 
sub-objectives or approaches relevant for the protection of the marine environment taking a nation State (State) perspective are suggested and outlined. All three approaches are relevant and necessary for States desiring to protect, conserve, or preserve the marine environment. The approaches focus on different targets or objects of management:

1. The mitigation approach that targets the reduction of human pressures on the marine environment regardless of where the impacts occur.

2. The impact approach that targets the combined impact of pressures on a smaller area such as a spatially defined marine area of a State.

3. The activities approach that targets the reduction of certain environmental harm caused by a confined set of activities operating within a marine area of a State.

The approaches have different implications in terms of necessary knowledge, relevant scale, and consistent responses. Moreover, the potential contributions to long-term protection of the marine environment differ depending on the approach. The IMM plans do not openly discuss which environmental problem aspects are appropriately addressed within their mandate. Nonetheless, the plans ambitiously aim for long-term protection of the marine environment, ${ }^{6}$ which requires adherence to all three approaches. To analyse the contribution of the plans to this aim, some essential implications of each of the three approaches are set out. Then the plans are analysed by content analysis ${ }^{7}$ to see if these implications are embedded in the plans. The degree of embedment enables an assessment of whether the plans adhere to the three approaches, and consequently to which of the approaches the plans contribute.

The question now is to which extent the case of Norway is relevant beyond the Norwegian context. Integrated marine management policies ${ }^{8}$ are not specific to Norway, but are part of a broad international trend. According to the national reporting system of the Convention on Biological Diversity (CBD), more than 30 countries have arrangements that fall under the heading of 'integrated ocean management' and at least 66 are developing arrangements for this type of management. ${ }^{9}$ However, 'integrated ocean management' has no uniform meaning, and may conceal multiple definitions and practical variants. Focusing on integrative concepts relevant for ocean management that use the term 'integrate', two international standards and norms exist. ${ }^{10}$ The first is the integration norm set out in Article 6 of the CBD and subsequent COP Decisions, which calls for integration of environmental, economic and social concerns

\footnotetext{
${ }^{6}$ Protecting the Riches of the Sea (n 2), at p. 7, for example, states the 'vision to safeguard a clean and rich sea, so that future generations can continue to harvest the wealth of resources that the sea has to offer'. This phrase is reiterated in each of the management plans, for example, in the Norwegian Sea IMM Update (n 2), at p. 5, 'maintaining a long-term, integrated marine environmental policy that is intended to facilitate value creation and at the same time protect the marine and coastal environment'.

${ }^{7} \mathrm{~K}$ Boréus and G Bergström, Analyzing Text and Discourse: Eight Approaches for the Social Sciences (Sage, London, 2017), at p. 24.

${ }^{8}$ On the terms 'policy' and 'plan', see (n 5).

${ }^{9}$ These figures are derived from the analysis tool based on the national reporting system under the Convention on Biological Diversity (CBD) (Rio de Janeiro, 5 June 1992, in force 29 December 1993) 1760 UNTS 79. According to the tool (Question 154), 33 countries have arrangements in place for the integrated management of marine and coastal ecosystems, six (of which two are landlocked States) have no such arrangements, 47 States consider themselves at the early stages of development of such arrangements, and 19 States consider themselves at an advanced stage of development. The analysis was conducted in August 2018, and the tool is available at https://www.cbd.int/reports/analyzer.shtml.

${ }^{10}$ L Schøning, 'More or less integrated ocean management: Multiple integrated approaches and two norms' (2019) 51(2) Ocean Development and International Law 95-115, at p. 2.
} 
into cross-sectoral policies and plans. ${ }^{11}$ Encompassing all these concerns, the IMM plans meet this norm. The second norm is based on a combination of the provisions in Agenda 21; the Protocol on Integrated Coastal Zone Management of the Barcelona Convention; CBD COP decisions, strategies and reports; and the integrated coastal management concept of PEMSEA. ${ }^{12}$ This norm provides that integrated ocean management plans and policies comprise management processes, rely upon the ecosystem approach, and aim for the protection and sustainable use of the marine environment. ${ }^{13}$ The Norwegian IMM plans also meet these criteria.

Despite the adherence to these international norms and standards bolstering the general relevance of the case of Norway, the plans are but a piece of a larger Norwegian context that may be more or less representative in comparison to other States. Nonetheless, the three approaches investigated here are general and have little bearing on country-specific factors. Moreover, although the jurisdictional powers vested in States to meet the environmental challenges are equal, ${ }^{14}$ the priorities and available resources may vary from State to State. Regardless, the scope of an integrated marine management policy will necessarily reflect a selfimposed restriction of these jurisdictional powers. ${ }^{15}$ These restrictions reflect how a State organises and delegates its affairs and the approach it applies. For example, Scott highlights that only Norway includes fisheries in its ocean management plans. ${ }^{16}$ Further, the IMM plans reflect the marine industrial interests (petroleum, marine food production, shipping, tourism,

\footnotetext{
${ }^{11}$ See, for example, CBD, COP Decision VII/II Ecosystem Approach, Doc UNEP/CBD/COP/DEC/VII/11, 13 April 2004, Annex 1, para 3, and Principle 5, at p. 12, available at https://www.cbd.int/doc/decisions/cop-07/cop07-dec-11-en.pdf; CBD, COP Decision IX/8 Review of implementation of goals 2 and 3 of the Strategic Plan, Doc UNEP/CBD/COP/DEC/IX/8, 9 October 2008, para 8(c) available at https://www.cbd.int/doc/decisions/cop09/cop-09-dec-08-en.pdf; Schøning (n 10), at p. 12.

${ }^{12}$ United Nations Conference on Environment and Development (UNCED), Agenda 21: Programme of Action for Sustainable Development, UN Doc A/CONF.151/26/Rev.1 (Vo1. I) (12 August 1992), Annex II; Protocol on Integrated Coastal Zone Management in the Mediterranean to the Convention for the Protection of the Marine Environment and the Coastal Region of the Mediterranean (Barcelona, 16 February 1976, amended 10 June 1995 , in force 24 March 2011) 1858 UNTS 402. Relevant CBD COP decisions, strategies and reports include COP Decision VII/5 Marine and coastal biological diversity, Doc UNEP/CBD/COP/DEC/VII/5, 13 April 2004, Annex 1:Elaborated Programme of Work on Marine and Coastal Biological Diversity, which adopts IMCAM in the first programme element, available at https://www.cbd.int/doc/decisions/cop-07/cop-07-dec-05-en.pdf; COP Decision VIII/22 Marine and coastal biological diversity: enhancing the implementation of integrated marine and coastal area management, Doc UNEP/CBD/COP/DEC/VIII/22, 15 June 2006, available at https://www.cbd.int/doc/decisions/cop-08/cop-08-dec-22-en.pdf; Action Plan for the Sustainable Ocean Initiative (2015-2020), available at www.cbd.int/doc/meetings/mar/soiom-2014-02/official/soiom-2014-02-actionplanen.pdf; AIDEnvironment, National Institute for Coastal and Marine Management/Rijksinstituut voor Kust en Zee (RIKZ), Coastal Zone Management Centre, The Netherlands, Integrated Marine and Coastal Area Management (IMCAM) Approaches for Implementing the Convention on Biological Diversity, CBD Technical Series No. 14 (Secretariat of the Convention on Biological Diversity, Montreal, 2004) available at www.cbd.int/doc/meetings/mar/imcam-01/other/imcam-01-cbd-ts-14-en.pdf; Secretariat of the Convention on Biological Diversity, Integrated Coastal Management for the Achievement of the Aichi Biodiversity Targets: Practical Guidance for Implementation Based on Experience and Lessons Learned from Coastal and Ocean Governance in the Seas of East Asia, CBD Technical Series No. 76 (2015) available at https://www.cbd.int/doc/publications/cbd-ts-76-en.pdf. The Partnerships in Environmental Management for the Seas of East Asia (PEMSEA) integrated coastal management (ICM) concept is set out in the ICM Code: Integrated Coastal Management (ICM) Code (PEMSEA, Quezon City, 2015) available at www.pemsea.org/ourwork/integrated-coastal-management/ICM-code.

${ }^{13}$ Schøning (n 10), at p. 8.

${ }^{14}$ Yet, the international and regional obligations undertaken by each State may vary.

${ }^{15}$ Schøning (n 10), at p. 4.

${ }^{16} \mathrm{KN}$ Scott, 'Integrated oceans management: A new frontier in marine environmental protection,' in Donald R Rothwell et al. (eds), Oxford Handbook of the Law of the Sea (Oxford University Press, Oxford, 2015) 463-490, at p. 471. However, the IMM plans adopted after Scott's article was published include fisheries in a more generally framed category of marine food production (see for example, Norwegian IMM Plans (n 2), at p. 68).
} 
and emerging marine industries) of Norway, as well as environmental interests. ${ }^{17}$ Moreover, applying these approaches will expose the scope of activities included in the plans. Nevertheless, the case of Norway illustrates how distinguishing between different environmental sub-objectives or problem aspects facilitates the investigation, structuring, and evaluation of contributions to marine environment protection and conservation.

\section{Problem Framing}

The problem analysis introduces a macroecological perspective, as per Burger et al. ${ }^{18}$ before focusing on the national ecological and governance context. The macroecological perspective is a global perspective of the entirety of Earth's environment and human interference therewith. It shows how human economies 'extract energy and material resources from the environment and transform them into goods and services' ${ }^{19}$ (the process). The production of energy and exploitation of resources, the transformation into goods and services, and the consumption thereof occur at a global scale, as resources, production facilities and end consumers often reside on different continents, thereby adding transportation to the process. Further, Burger et al. note how human economies in the process 'create waste products that are released back into the environment' ${ }^{20}$

Can the Earth support even current levels of human resource use and waste production? ... The emphasis on local and regional scales ... is largely irrelevant if the human demand for essential energy and materials exceeds the capacity of the biosphere to absorb or detoxify these substances. ${ }^{21}$

Multiple scientific reports find that the state of the global ocean environment (constituting roughly 70 per cent of the Earth's surface) is alarming. ${ }^{22}$ The macroecological perspective therefore challenges the relevance of local and regional scales, and hence the national scale, in light of the biosphere's limited capacity. ${ }^{23}$ To add to the complexity, whereas the environmental effects of these processes are largely known, impacts may be spread out globally, and may only be detected on an aggregated level (such as $\mathrm{CO}_{2}$ ). This implies that detecting all the processes that have had impact on the ecology of a confined area is impossible. How nation States should approach the protection of the marine environment in light of the

\footnotetext{
${ }^{17}$ Norwegian IMM Plans (n 2), at pp. 67 and 18 respectively.

18 JR Burger et al., 'The Macroecology of Sustainability' (2012) 10(6) PLoS Biology e1001345.

${ }^{19}$ Ibid., at p. 2.

${ }^{20}$ Ibid.

${ }^{21}$ Ibid., at p. 4.

${ }^{22}$ Group of Experts of the Regular Process, The First Global Integrated Marine Assessment, World Ocean Assessment 1 (United Nations, 2016) [WOA1]; Intergovernmental Panel on Climate Change (IPCC), '2019: Summary for policymakers', in H-O Pörtner et al. (eds), IPCC Special Report on the Ocean and Cryosphere in a Changing Climate (IPCC, in press); Intergovernmental Science-Policy Platform on Biodiversity and Ecosystem Services (IPBES), The Global Assessment Report on Biodiversity and Ecosystem Services: Summary for Policymakers (IPBES Secretariat, Bonn, 2019).

${ }^{23}$ The limited biosphere capacity is also reflected in research on planetary boundaries. See J Rockström et al., 'Planetary boundaries: Exploring the safe operating space for humanity' (2009) 14(2) Ecology and Society 32; W Steffen et al., 'Planetary boundaries: Guiding human development on a changing planet' (2015) 347(6223) Science 1259855. Further, this is evident in the IMM plans. For example, in the Norwegian Sea IMM Plan (n 2), Chapter 3.3.1 identifies the main source of long-range pollutants transported by air and ocean currents, and the Norwegian IMM Plan (n 2), at p. 58, holds that 'Norwegian marine areas are part of a connected ocean system, and what happens in other parts of the world's oceans also influences Norwegian marine areas. The development of Norwegian ocean management must build upon an understanding of how climate change and other large-scale changes influence and will change the oceans of the world' (author's translation).
} 
macroecological perspective, where both human pressures and their effects play out at global scale, is not immediately clear. Therefore, it is suggested that management instruments and scholarly literature focusing on the protection of the (marine) environment reveal their understanding of the greater problem complex and link efforts to aspects of it that they address. This article serves as an attempt at such problem framing.

Although Burger et al. question the relevance of confined scales from a macroecological perspective, the national scale is certainly relevant for governance or management purposes. Within the global governance system, States are the actor with designated formal powers (jurisdictional capacities) over humans and their activities ${ }^{24}$ that are relevant for addressing global processes from a macroecological perspective. Moreover, the United Nations Convention on the Law of the Sea requires States to protect and preserve the global marine environment. ${ }^{25}$ Certainly coastal States have a particular interest in their 'own' marine areas, where they have extended entitlements, which serve as an important source of resources. ${ }^{26}$ However, in light of global biospheric constraints, if global pressures are not relieved, longterm protection of the environment cannot be achieved at any scale.

Despite the powers and obligations vested in States, the potential contribution of any nationally-scaled environmental efforts arguably can be questioned. How can national efforts respond to global processes ranging from resources and energy to waste? Several approaches can be envisioned. Each sovereign State contributes to a proportion of the global pressures by national resource extraction and energy production, as well as by demand, import, production, export, and consumption of goods and services by its citizens and entities. Reducing this proportion, or the environmental effects of these activities or pressures, contributes to global environmental protection. Alternatively and additionally, an individual State can reduce concentrations of detectable pressures on a local area, if these pressures are under the jurisdiction of that State. A State can, for example, restrict resource-exploiting activities operating in a marine area in order to protect fragile ecosystems or to implement their duty to integrate environmental concerns into decision-making concerning those activities (the integration principle). ${ }^{27}$ However, these activities may not constitute the main threat to the area. Finally, States can monitor impacts of pressures in local areas to assess status trends.

What is the potential environmental contribution of an integrated marine management policy of a State in the face of the complexity of this ecological and governance problem? The policy likely only addresses some aspects of the problem. Hence, in light of the problem complexity outlined above, the contribution to marine environmental protection of any State's integrated marine policy, including the Norwegian IMM plans, is limited. Moreover, the scope of an integrated marine policy likely covers only some of a State's range of environmental efforts. As most human activities have a direct or indirect effect on the environment, management efforts that may be deemed relevant for marine environmental protection may be spread across multiple regulatory and management instruments in the national system into which an integrated ocean management policy is embedded. This complexity demonstrates the appropriateness of a holistic account of the management efforts, such as an integrated ocean

\footnotetext{
${ }^{24}$ I Brownlie, Principles of Public International Law, 7th ed. (Oxford University Press, Oxford, 2008), at p. 289; United Nations Convention of the Law of the Sea (Montego Bay, 10 December 1982, in force 16 November 1994), 1833 UNTS 396 [LOSC], Articles 2 and 56, which define the sovereign and jurisdictional rights of the State, and Article 193, which recognises the sovereign right of States to exploit their natural resources.

${ }^{25}$ LOSC, ibid., Article 192, which imposes a general obligation on States to protect and preserve the marine environment.

${ }^{26} \mathrm{Ibid}$., Article 2, which provides a coastal State sovereignty over the territorial sea, and Article 56, which provides sovereign rights to living and non-living resources in the exclusive economic zone, as well as limited jurisdictional rights.

${ }^{27}$ CBD (n 9), Article 6(b); see also Schøning (n 10), at pp. 8-12.
} 
management policy, to synthesise and combine the most relevant efforts. This analysis attempts to assist such instruments by bringing forward some important problem aspects and relevant approaches. Still, the complexity of national regulatory and management systems limits the relevance of the analysis of a single instrument. Yet, as the plans 'clarify the overall framework ... for management of Norway's sea areas, ${ }^{28}$ this limitation does not outweigh the benefits of aligning this overall framework with certain aspects of the problem. In any case, global ecological and governance complexity bolsters the need to unwrap problem aspects of marine environmental protection. Three of these and how States may approach them are discussed below.

\section{Three Approaches to Marine Environmental Protection}

\section{The Mitigation Approach: Reducing Pressures}

The mitigation approach targets the reduction or mitigation of human pressures on or threats to the marine environment regardless of where the impact occurs. Multiple scientific reports on the status of the global marine environment indicate the urgency of addressing human threats to the ocean, ${ }^{29}$ and call for a reduction or mitigation of these pressures. ${ }^{30}$ The mitigation approach faces the challenge of alleviating intolerable pressure on ecosystems caused by humans. It differs from approaches targeting the impacts on ecosystem as it focuses on the human pressures. Although the pressures and their impacts certainly are related, for some management purposes it may be relevant to separate them. Managing pressures allows for targeting, for example, of the main or fundamental pressures, in light of the macroecological perspective, or root causes thereof, as well as the pressures whose effects are spread out globally.

This approach targets all relevant pressures, not just climate change, although the concept of mitigation is frequently referred to in climate change law and management. ${ }^{31}$ This prompts the question: What are the relevant pressures beyond climate change? For States aiming to mitigate the pressures, understanding the main or fundamental pressures, or the pressures that need to be reduced, is vital knowledge. Further, the State perspective of the analysis begs the question of what the relevant scale is. In light of the problem framing, the scale of human interference with the environment is global.

The governance system's vesting of formal power in 200 sovereign States prompts the question of whether it is a responsibility of States, such as Norway, to protect the global marine environment, and whether it appropriate for a single State such as Norway to consider threats to the global marine environment in the management of its 'own' marine areas. States are obliged to protect the global marine environment. ${ }^{32}$ Any marine area depends on protection at

\footnotetext{
${ }^{28}$ Norwegian IMM Plans (n 2), at p. 5; Norwegian Sea IMM Update (n 2), at p. 5.

${ }^{29}$ See WOA1, IPPC, and IPBES (n 22).

${ }^{30}$ Mitigation is used in the meaning 'the act of decreasing or reducing something, or hinder or prevent something', as per the American Heritage Dictionary of the English Language (Fifth Edition, Houghton Mifflin Harcourt Publishing Company, 2016). The IPCC uses mitigation in a similar fashion, defining mitigation of climate change as 'a human intervention to reduce emissions or enhance the sinks of greenhouse gases' (IPCC (n 2), Annex I at p. 692). In contrast, the United Kingdom Marine Monitoring and Assessment Strategy (UKMMAS) defines mitigation more narrowly, as something not capturing preventative measures (which would also reduce pressures), but as those controls that aim to reduce the impact of a change if it does occur (UKMMAS, 'Marine online assessment tool, Cumulative effects of human activities' available at https://moat.cefas.co.uk/uses-of-the-marineenvironment/cumulative-effects-of-human-activities/).

${ }^{31}$ However, only some entities define the term, for example, the IPCC (n 22), Annex 1, at p. 692: 'Mitigation (of climate change) [means] a human intervention to reduce emissions or enhance the sinks of greenhouse gases (GHG)'.

${ }^{32}$ LOSC (n 24), Article 192.
} 
all scales, including global, regional, and local. ${ }^{33}$ Furthermore, migrating species and ocean currents call for attention on a large scale if the aim is marine environmental protection, in spite of confined mandates. Thus, protection of the global marine environment is not just an obligation for States, but also an appropriate perspective in protecting and conserving the environment of a State's 'own' marine areas.

Each State contributes a proportion of the global pressures, which potentially can be reduced, even though each State cannot solve the problem alone. Thus, a pertinent management scale for a State is its contribution to the pressures and its jurisdictional capacities and roles providing opportunities to reduce them. These jurisdictional capacities include territorial and jurisdictional rights in a spatially confined area; authority over national citizens and activities; flag, port and market State capacities; and their role as a member of the international community. ${ }^{34}$ Multiple management responses can be anticipated, such as reducing the environmental effects of national resource extraction and energy production, by management of demand, import, production, export, and consumption of goods and services by national citizens and entities.

\section{The Impact Approach: Impact on a Limited Area}

In contrast to the mitigation approach, the impact approach targets the impact of pressures, meaning pressures as determined by impacts on a certain area. This approach captures pressures that have detectable or assessable impact in a defined area or have an impact on certain species or ecosystem components. The relevant area could be a spatially defined marine area of a State. Each habitat may respond uniquely to each pressure since global pressures play out differently in different areas. Depending on the characteristics of ecosystems and concentrations of pressures, ${ }^{35}$ ecosystems may be more or less vulnerable or robust to pressures. Even though the global pressures on the marine environment need to be reduced generally, the impact capacity of a specific area may vary, meaning that some areas tolerate pressure better than others.

The impact approach provides for assessing the status or impact capacity of ecosystems in terms of, for example, environmental status, vulnerable or robust habitats, species, ecosystems, or areas. The relevant scale depends on how effects play out in marine ecosystems, natural systems and on single species, the extent to which this is possible to assess, and the choice of scale. If the impact capacity is expressed as an environmental status, that status may depend on the choice of scale. For example, whereas the environmental status of the three Norwegian ocean areas vary (the Barents Sea is considered as good, the Norwegian Sea as good with a few exceptions, and the North Sea and Skagerrak as 'concerning and in some areas unsatisfactory'), ${ }^{36}$ the status of the ocean areas combined are presented as 'in many respects good, but increasingly influenced by climate change'. ${ }^{37}$

\footnotetext{
${ }^{33}$ As explained in the problem-framing section above.

${ }^{34}$ BS Halpern et al., 'Managing for cumulative impacts in ecosystem-based management through ocean zoning' (2008) 51(3) Ocean \& Coastal Management 203-211, at p. 209 refers to the relevance of jurisdiction in relation to scale, but by referring to jurisdictional boundaries, the jurisdictional capacities that are not spatially confined are left out.

${ }^{35}$ BS Halpern et al., 'Evaluating and ranking the vulnerability of global marine ecosystems to anthropogenic threats' (2007) 21(5) Conservation Biology 1301-1315, at p. 1302.

${ }^{36}$ Environmental status of Barents Sea and Norwegian Sea, Norwegian IMM Plans (n 2), pp. 19 and 33 , respectively. The status for the North Sea and Skagerrak was last described in general terms in the North Sea IMM Plan (n 2), at p. 19. The approach to environmental status as applied in the IMM plans is a Norwegian policy concept.

${ }^{37}$ Norwegian IMM Plans (n 2), at p. 18; see also the official environmental status pages of the Norwegian Environment Agency, available at https://miljostatus.miljodirektoratet.no/tema/hav-og-kyst/.
} 
The knowledge required by the impact approach includes an overview of marine ecosystems in order to establish categories that enable managers to prioritise areas or to take any relevant measures to protect ecosystem components. Examples of these categories can be environmental status or vulnerable or robust areas or components. The establishment of categories requires knowledge both of the ecosystem as such and the cumulative pressures thereon, to the extent that such knowledge is possible to obtain. Generally, ecosystems are subject to multiple pressures, but while assessing which exact pressure an impact stems from is easy in some instances, in most it is challenging, if not impossible. ${ }^{38}$ Any categorising or assessing of an impact on an area therefore always comes with some uncertainty. Using vulnerability or robustness as the criterion for categorising knowledge has implications for the burden of proof. Determining which natural systems are robust enough to tolerate a certain level of activity (for example, the existing level of activity or an expansion into new activities) requires knowledge indicating the robustness of that natural system. Determining which natural systems are vulnerable to activities calls for knowledge indicating the vulnerability of the natural system. Therefore, the choice of perspective may influence the categorisation of the status of an area, whether robust or vulnerable, given the uncertainty attached to establishing links between activities and their impacts. ${ }^{39}$

In any event, some activities located in a designated area will fall under the authority of the management regime. Thus, for impact management purposes, one could focus on specific activities with traceable or assessable impact on the area or on components of the area. In light of the uncertainty attached to these assessments, no obvious management response exists, except restricting those specific activities with a traceable or likely impact on a vulnerable ecosystem or species, or relocating those activities to robust areas. Thus, the concentration of specific activities may be redistributed or reduced, even though these manageable pressures may not be the most harmful pressures on the ecosystems in question. In light of the uncertainty attached to categorisation and assessment of marine areas, any management response relying on categories or assessments of impacts or status should do so with (pre)caution. ${ }^{40}$

\section{The Activities Approach: Reducing Some Effects of Certain Activities}

Unlike the mitigation and impact approaches, the starting point and the target of the activities approach are multiple activities operating within a geographically confined area (not environmental pressures or impacts). This approach facilitates the avoidance of the effects of certain individual or combined activities in that area on, for example, particular species or habitats. The set of activities included may be those activities occurring in a spatially defined area.

It is worth noting, however, that this approach primarily facilitates activities, which always results in some negative environmental effects. Secondarily, it seeks to reduce some of those effects. In total, this means that an activities approach most likely increases negative environmental effects simply by increasing activities. Therefore, the activities approach has a net negative effect on the environment. Yet, reducing environmental harm in the context of an

\footnotetext{
38 'It is of course difficult, if not impossible, to experimentally control for all possible ecosystem drivers, and so we are left to make inferences from studies that examine one to at most a few threats'. Halpern et al. (2008) (n 34), at p. 208.

${ }^{39}$ In the context of the impact approach, the focus here is on (semantic) categories, not ecologically determined categories. The reason for this is a general hesitance to assume that one can deduce how management should respond on the basis of ecological knowledge of a small area in light of the macroecological perspective presented in the introduction above.

${ }^{40}$ N De Sadeleer, 'The risk of risk analysis' (2017) 8(1) European Journal of Risk Regulation 28-32, at p. 29, argues how 'the precautionary principle and the principles of scientific rigour are not antithetical, but rather mutually reinforcing'.
} 
activities approach is certainly relevant. Including environmental concerns under this approach would further reflect the integration principle-while planning for activities, environmental concerns must be taken into account. ${ }^{41}$ The activities approach may coincide with other purposes of coordination, such as co-existence and distribution of spatial areas to maximise resource use and outtake. When taking an activities approach, the scale of selected activities and their selected effects can be adjusted to match, for example, an area where certain activities occur, that is, a spatially defined area within the administrative or jurisdictional boundaries a State that coincides with the scope of a marine management regime.

For States taking an activities approach, the optimal knowledge input would be the effect of those activities that have a detectable or assessable impact on the ecosystems within the confined area of the selected activities (however, assessing the impact that stems from a particular activity is easy in some instances, but challenging if not impossible in most). ${ }^{42}$ Excluded from the approach are pressures from the selected activities that have effects outside the area (which may be subject to different management regimes), and effects on the area by activities outside the scope of the approach.

Moreover, some effects may be deselected as inappropriate with regard to aggregation level. For instance, the detectable or assessable impact of petroleum production in a given ocean area include extraction of a non-renewable resource from the seabed; damage to the seabed; the disturbance caused by pipeline structures and platforms; exhaust and pollution from platforms, supply vessels, oil service industries and helicopters; and physical occupancy by coastal landing facilities. These impacts are more or less appropriate to target within the activity's context. If abating climate change is a concern, targeting the exhaust of single platforms is likely an inappropriately low level to regulate unless it forms part of an overall plan targeting energy source composition, energy consumption of a State, or energy produced or used by an industry. Seabed damage and pipelines may, however, be appropriately targeted alongside seabed damage caused by bottom trawling. Management responses should therefore target the reduction of environmental effects that are appropriately addressed within the confined scope and scale of the activities approach.

It should be noted that the activities approach separates knowledge input from management responses. This means that the 'measure' of obtaining knowledge is not a management response. This is a narrower interpretation than use of the term 'measure' in the IMM plans. As noted by Sander, knowledge gathering is by far the most frequent measure identified in the former IMM plan for the Barents Sea. ${ }^{43}$ Yet, as recognised in the 2019 report on the scientific basis to the IMM plan for Norwegian marine areas,

increased knowledge related to mapping and monitoring does not always lead to an improved understanding of the status of the respective ecosystems. Neither is it immediately evident how increased knowledge can or should be used in the management of the ocean areas. ${ }^{44}$

Thus, management responses under the activities approach do not encompass knowledge gathering.

\footnotetext{
${ }^{41}$ CBD (n 9), Article 6(b).

${ }^{42}$ Halpern et al. (2008) (n 34).

${ }^{43} \mathrm{G}$ Sander, 'Against all odds? Implementing a policy for ecosystem-based management of the Barents Sea' (2018) 157 Ocean \& Coastal Management 111-123, at pp. 116-117, investigating the Barents Sea and Lofoten IMM.

44 Professional Forum for Norwegian Sea Areas, Sammendrag av det faglige grunnlaget for revisjon og oppdatering av forvaltningsplanene for havområdene, [Summary of the scientific bases for revision and update of the management plans for the marine areas], Report No. M-1350 (2019), at p. 46 (author's translation), available at https://tema.miljodirektoratet.no/no/Havforum/Forside/Publikasjoner/publikasjoner-fra-Faglig-forum/.
} 


\section{Compiling and Contrasting the Three Approaches}

The mitigation, impact and activities approaches call for a different scale, knowledge input, and management response tailored to each of their targets. Whereas all three approaches contribute to improvement of the marine environment, their potential contributions or achievements differ. As it targets the main threats to the environment, the mitigation approach, when applied by a majority of States, may lead to long-term protection and conservation of the marine environment. The other two approaches may contribute to a relatively improved environment compared to where they are not applied. Even if applied systematically by a majority of States, the impact and activities approaches would not lead to long-term protection and conservation of the marine environment as they only capture a selection of pressures - a selection that does not capture fundamental, main or necessary pressures, but those relevant for a more limited purpose. Therefore, regardless of the harm reduction or environmental improvement, the impact and activities approaches are not designed to abate the fundamental threats to the environment; accordingly, they will not lead to long-term protection and conservation of the marine environment. Table 1 outlines the three approaches and some of their diverging implications.

TABLE 1 Comparison of the three approaches to marine environmental protection

\begin{tabular}{|c|c|c|c|c|c|}
\hline Approach & Target & Scale of target & $\begin{array}{l}\text { Knowledge } \\
\text { required } \\
\text { (ideally) }\end{array}$ & $\begin{array}{l}\text { Management } \\
\text { response }\end{array}$ & Contribution \\
\hline Mitigation & Pressures & $\begin{array}{l}\text { Global } \\
\text { Additional } \\
\text { regional or } \\
\text { local pressures } \\
\text { in some areas }\end{array}$ & $\begin{array}{l}\text { Main pressures } \\
\text { and how to abate } \\
\text { them }\end{array}$ & $\begin{array}{l}\text { Reduce } \\
\text { pressures }\end{array}$ & $\begin{array}{l}\text { Long-term } \\
\text { protection and } \\
\text { conservation of } \\
\text { the global } \\
\text { marine } \\
\text { environment }\end{array}$ \\
\hline Impact & $\begin{array}{l}\text { Impacts of } \\
\text { pressures }\end{array}$ & $\begin{array}{l}\text { Spatially } \\
\text { limited area }\end{array}$ & $\begin{array}{l}\text { Impact capacity } \\
\text { of area, including } \\
\text { ecosystems, } \\
\text { natural systems, } \\
\text { or single species }\end{array}$ & $\begin{array}{l}\text { Locating, } \\
\text { relocating, or } \\
\text { restricting } \\
\text { local } \\
\text { manageable } \\
\text { pressures }\end{array}$ & $\begin{array}{l}\text { Reduce some } \\
\text { environmental } \\
\text { harm }\end{array}$ \\
\hline Activities & $\begin{array}{l}\text { Certain } \\
\text { effects of } \\
\text { certain } \\
\text { activities }\end{array}$ & $\begin{array}{l}\text { Certain } \\
\text { activities, for } \\
\text { example, } \\
\text { operating in a } \\
\text { spatially } \\
\text { confined area }\end{array}$ & $\begin{array}{l}\text { Combined effects } \\
\text { of } \quad \text { certain } \\
\text { activities } \\
\text { certain } \\
\text { ecosystems }\end{array}$ & $\begin{array}{l}\text { Locating, } \\
\text { relocating, or } \\
\text { restricting } \\
\text { activities }\end{array}$ & $\begin{array}{l}\text { Certain local } \\
\text { harmful effects } \\
\text { are reduced }\end{array}$ \\
\hline
\end{tabular}

Some other environmental problem aspects fall beyond the scope of the three approaches, such as the clean-up of pollution and accumulated waste; the management of acute pollution risks; and some alternative measures to mitigation. ${ }^{45}$ Thus, the three approaches do not constitute a comprehensive system of management for marine environmental protection, but rather a set of complementary approaches. The mitigation approach is arguably fundamental and a generic approach to the most important problem aspect of (marine) environmental

\footnotetext{
${ }^{45}$ The alternatives to reducing pressures include measures that absorb or transform some portion of a pressure, for example, carbon capture and storage, kelp aquaculture and ocean iron fertilization.
} 
protection. In contrast, the impact and activities approaches are tailored to the State-level marine management context. Thus, the three approaches are not intended to have universal relevance for marine ecosystem management. They are tailored to a specific research question and management context.

The three approaches are related and indivisible in some ways. Whether positive or negative, impact trends (outputs of the impact approach) may feed into the discussion of relevant management responses under the activities approach. Further, the reduction of pressures (management response under the mitigation approach), expressed for example in terms of which activities States should consider, could be relevant for deciding tolerated activities that are a premise for the activities approach. Furthermore, the impact and activities approaches mirror each other in terms of management response, but do not necessarily capture the same activities.

The three approaches may resemble the DPSIR (drivers-pressures-status-impactresponse) approach and derivatives. ${ }^{46}$ Yet, unlike DPSIR the three approaches highlight the diverging implications of pressures and impacts for management. Further, the uncertainty attached to the impact (and status) approach, and the subsequent lack of obvious management responses, highlights the need to focus on responding to the pressures, the environmental effects of which are largely known, as opposed to tracing impacts of combined or individual activities in the environment. Assessing impacts on a confined area or by a limited set of activities will contribute only to solving local, limited and short-term problems, as long as global pressures are defined as out-of-scope.

\section{Application to the Norwegian IMM Plans}

Identification of the applied targets, scales, knowledge bases and management responses allows for assessment of the contribution of each of these three approaches. The implications of each approach as embedded in the Norwegian IMM plans will be considered in turn following a brief introduction of these plans.

\section{Introducing the Plans}

The IMM plans do not endorse the categorisation of these three approaches, which is novel to this article. Yet, it is clear that the plans aim for the contributions resulting from all three approaches. The potential contribution of the mitigation approach is, for example, evident in the "vision to safeguard a clean and rich sea, so that future generations can continue to harvest the wealth of resources that the sea has to offer', ${ }^{47}$ and in the statement that ' $[\mathrm{t}] \mathrm{he}$ Norwegian marine areas shall be managed to preserve the diversity of ecosystems, nature types, species, and genes, and to maintain ecosystem productivity' ${ }^{48}$ Further, the contribution of the impact approach is evident in, for example, the goal that 'the management regime will take special account of the need to protect vulnerable habitat types and species in particularly valuable and vulnerable areas', ${ }^{49}$ and that the '[p]opulations of endangered and vulnerable species and species for which Norway has a special responsibility will be maintained or restored to viable levels'. ${ }^{50}$ Further, the contribution of the activities approach is reflected in the goals that

\footnotetext{
${ }^{46} \mathrm{~J}$ Patrício et al., 'DPSIR - Two decades of trying to develop a unifying framework for marine environmental management?' (2016) 3 Frontiers in Marine Science article 177.

${ }^{47}$ Protecting the Riches of the Sea (n 2), at p. 7. Each of the management plans (n 2) reiterates this vision.

${ }^{48}$ Norwegian IMM Plans (n 2), at p. 15 (author's translation).

${ }^{49}$ Ibid.

${ }^{50}$ Ibid.
} 
'activities shall be conducted in such manner that all ecological functions are maintained' ${ }^{51}$ and 'the overall level of activity is adjusted to take account of environmental considerations'. ${ }^{52}$ This raises the question of whether the plans possibly contribute to these goals. A fine line exists between vivid, visionary language and promises and commitments to objectives. Yet, one can interpret the IMM plans as a genuine attempt to protect the marine environment, as reflected not just in these formulations, but also in the scientific and administrative resources invested in the plan-making procedures, their adoption at the highest ministerial level, their political importance as reflected in their inclusion in majority government platforms, and the final endorsement of the plans by the Norwegian Parliament.

As the plans attempt to protect the Norwegian marine environment, they call for some geographical and environmental elaboration. Norway's vast and resource rich marine areas amount to more than two million square kilometres. ${ }^{53}$ To manage these areas, Norway has adopted IMM plans for marine areas where it has extended entitlements. ${ }^{54}$ The marine areas to which the IMM plans apply span from the intensively used Skagerrak and North Sea to the relatively less but still much used Norwegian Sea, to the less used areas of the Barents Sea. Until the most recent IMM plans were adopted in 2020, previous plans spatially divided these ocean areas into three individual plans for the North Sea and Skagerrak (North Sea), Norwegian Sea, and the Barents Sea and Lofoten (Barents Sea) respectively. ${ }^{55}$ The division, which is based on ecological and administrative considerations, is still evident in the recent plans and in the description of the Norwegian policy concept of environmental status of the areas. Excluded from the plans' scope are, broadly speaking, internal waters, coastal areas and fjords. ${ }^{56}$ The plans build on so-called scientific bases or factual bases for the plans. ${ }^{57}$ Naturally, the plans and factual bases are mutually dependent on each other. The knowledge provided sets premises for and gives direction to the plans, for instance, with regard to whether a plan focuses on reducing pressures, or considers the impact of pressures or certain activities.

The IMM plans are but a piece of the Norwegian environmental and activities management and regulatory system. ${ }^{58}$ Relying on existing instruments, institutions, and budgets, they constitute an overview and offer an overarching regulatory layer by repeating, yet connecting and coordinating management measures aimed at marine environmental protection and conservation. The plans have a wide set of ambitions, such as sustainable use of the areas, facilitating the operations of industries and their co-existence, and contributing to employment in coastal regions. ${ }^{59}$ More implicitly, plan-making procedures result in knowledge production, function as a coordination instrument for ministries and directorates, and provide for

\footnotetext{
${ }^{51}$ Ibid. Expressed in relation to certain marine nature types.

52 Norwegian Sea IMM Plan (n 2), at p. 12.

53 The territorial sea, exclusive economic zone and fisheries protection zones around Svalbard and Jan Mayen amount to 2,031,734 square kilometres, according to the Norwegian Mapping Authority (https://www.kartverket.no/Kunnskap/Fakta-om-Norge/Sjoarealer/Sjoomrader/; accessed 29 October 2018).

${ }^{54}$ See LOSC (n 24).

${ }^{55}$ North Sea IMM Plan (n 2); Norwegian Sea IMM Plan (n 2); Barents Sea IMM Plan (n 2).

${ }^{56}$ Norwegian Sea IMM Plan (n 2). One exception is part of the Vestfjorden, which is included due to its ecological importance.

57 The scientific or factual bases consist of multiple documents that assess the socio-economics activities operating in the marine areas and the effects of these activities on the environment, and provide ecological assessments and summaries thereof. The reports (in Norwegian) are available at https://havforum.miljodirektoratet.no/kunnskapsgrunnlaget/.

58 The IMM plans comprise one set of instruments of a larger regulatory system. On the Norwegian regulatory system, and how a set of instruments cannot exhaustively depict the law, see JC Fløysvik Nordrum, Bedre Regulering?: Årsak-Virkningsanalyser I Norsk Reguleringsprosess, 1st ed. (Gyldendal, Oslo, 2019)., at pp. 106107 (in Norwegian).

${ }^{59}$ Norwegian IMM Plans (n 2), at p. 15.
} 
parliamentary review of Norwegian ocean policies. Nonetheless, the analysis here focuses on the IMM plans' contribution to environmental objectives in terms of the mitigation approach, the impact approach, and the activities approach.

\section{The Mitigation Approach of the IMM Plans}

The Norwegian IMM plans do not explicitly target the general reduction of pressures in the sense that reduction of pressures is not set out as an aim. Nonetheless, the plans identify some pressures and capture certain measures. The extent to which these efforts align with the mitigation approach in terms of target, scale, knowledge, and management response is examined below.

The IMM plans proclaim to be a tool for the preservation of the Norwegian marine areas. Yet, these areas nonetheless depend on preservation at all scales as per the macroecological perspective. The recent IMM plans explicitly acknowledges this, pointing to how the Norwegian marine areas are part of a connected ocean system affected by what happens in other parts of the world's ocean, and 'that the entire system is exposed to climate change and other large-scale influences'. ${ }^{60}$

Further, the IMM plans refer to how the Intergovernmental Science-Policy Platform on Biodiversity and Ecosystem Services (IPBES) report on the global assessment of biodiversity and ecosystem services has identified five direct drivers or main pressures on the global marine environment. ${ }^{61}$ These are (where the first and second are ranked as those with greatest impact):

1. Fisheries and other harvesting of marine organisms;

2. Change in area use on land and at sea, including development of infrastructure and aquaculture in the coastal zone;

3. Climate change;

4. Pollution and waste; and

5. Invasive and alien species. ${ }^{62}$

Although the IMM plans list these pressures, they do not explicitly subscribe to them. Rather, they identify climate change as the pressure with greatest impact on Norwegian marine areas, and move on to focus on its impacts. ${ }^{63}$ Further, the plans assess the pressure of certain local activities on the marine areas. ${ }^{64}$

The IMM plans, as mentioned above, explicitly identify the third pressure (climate change). Although the main focus is on the impact of this pressure, the plans also briefly

\footnotetext{
${ }^{60}$ Ibid., at p. 58 (author's translation).

${ }^{61}$ The IPBES report (n 22) (at p. 12) list of five direct drivers could be aligned with the main pressures on the global marine environment as per the WOA1 (n 22). Chapter 54 of WOA1 identifies seven main pressures: climate change; fishing; marine pollution; increased demand for marine space; underwater noise; interfering constructions; non-native species. In alignment, these are roughly similar considering that the second of the IPBES report direct drivers include interfering structures, and since pollution as IPBES report direct driver includes noise. Because the direct drivers of the IPBES report align with the main pressures as per WOA1, they are both categorized as main pressures for the remaining of the analyses. The reference in the Norwegian IMM Plans (n 2) document to the IPBES report at p. 7 (the summary) mentions all five direct drivers, whereas at p. 59 only four are mentioned (invasive and alien species are excluded). It is assumed here that the latter is an error. The full IPBES report, in Chapter 2.1.12 overview of direct drivers, at p. 105, provides details on these five direct drivers (available at https://ipbes.net/sites/default/files/ipbes_global_assessment_chapter_2_1_drivers_).

${ }^{62}$ IPBES report (n 22), at p. 12.

${ }^{63}$ Norwegian IMM Plans (n 2), at p. 59.

${ }^{64} \mathrm{Ibid}$., at p. 74, 81, and 88. However, this document does not include a description of the collective impact of these selected activities. Assessing the collective impact on a limited area is challenging using the macroecological perspective.
} 
describe and refer to some knowledge, some potential management efforts, and some implemented management efforts in response to climate change. ${ }^{65}$ The plans clearly identify the fourth pressure (pollution and waste) in the descriptions of environmental status of the different ocean areas. ${ }^{66}$ The plans include only some management responses to this pressure, referring, amongst others, to how many of these inputs are transported from other countries. How Norwegian citizens or activities contribute to these inputs is not problematised ${ }^{67}$ Further, the plans identify the fifth pressure (invasive and alien species), and include one measure to reduce the number of Pacific oysters, ${ }^{68}$ noting, however, that former plans included further measures to this end. ${ }^{69}$

The plans also identify the first pressure (fisheries and harvesting). The IMM plans state that fisheries have a great impact on ecosystems, ${ }^{70}$ and a former plan has stated how the 'human activity that currently puts most pressure on the Norwegian Sea during normal activities is the fisheries'. ${ }^{71}$ Yet, the plans do not discuss the global scope of this pressure, how it affects Norwegian fisheries management, and the many ways beyond fisheries management that Norway could influence this global pressure. Nonetheless, a former IMM plan does refer to some responses to this global pressure, such as illegal, unreported and unregulated (IUU) fishing measures, port State and market State measures, and international cooperation. ${ }^{72}$

Whether the IMM plans identify the second pressure (change in area use on land and at sea, including development of infrastructure and aquaculture in the coastal zone) is difficult to evaluate. Generally, the plans call for increased use of the ocean by existing and emerging industries, including marine aquaculture, in all marine areas. ${ }^{73}$ The plans also include restrictions on certain activities, such as banning petroleum activities from some areas and facilitating protected marine areas. ${ }^{74}$ Regardless, the increased use of, for example, the North Sea, 'Norway's most intensively used sea area and one of the most heavily trafficked in the world' ${ }^{75}$ is not problematised in the discussion of or responses directed at reducing the intensity of uses. Rather, the plans promote the strengthening of 'continued value creation through use

\footnotetext{
${ }^{65} \mathrm{Ibid}$., at pp. 59-66 , 130, and 90 respectively. Beyond the IMM plans, certain goals for the purpose of climate change mitigation are included in the Act relating to Norway's Climate Targets (Climate Change Act) (LOV-201706-16-60). Existing measures to meet these goals are spread across multiple regulatory instruments, including the Greenhouse Gas Emission Trading Act of 17 December 2004 and the Act relating to Tax on Discharge of $\mathrm{CO}_{2}$ in Connection with Petroleum Activities on the Continental Shelf of 21 December 1990. A climate change policy has yet to be adopted with measures to achieve these aims while targeting emissions of multiple sectoral activities.

${ }^{66}$ Norwegian IMM Plans (n 2), at pp. 20, 40, 47, 49. Beyond the IMM plans, measures to reduce pollution and waste include the Act concerning Protection against Pollution of 13 March 1981 and concerning Waste and the White Paper on Waste Policy and Circular Economy (Meld. St. 45 (2016-2017)).

${ }^{67}$ Norwegian IMM Plans (n 2), at p. 139.

${ }^{68}$ Ibid., at pp. 39, 139.

${ }^{69}$ With regard to ballast water, the North Sea IMM Plan (n 2), at chapter 3.2.10, refers to response measures set out in the international regulations under the Ballast Water Management Convention. Further, the IMM plans refer to some measures concerning inputs and clean-up of marine (plastic) pollution (e.g., North Sea IMM Plan (n 2), chapter 4.2), but do not discuss the range of measures available. Beyond the IMM plans, the Act No. 100 relating to the Management of Biological, Geological and Landscape Diversity of 19 June 2009 includes restrictions on the introduction of alien species.

${ }^{70}$ Norwegian IMM Plans (n 2), at p. 74.

${ }^{71}$ Norwegian Sea IMM Plan (n 2), at p. 55.

${ }^{72}$ Ibid., at p. 133.

${ }^{73}$ Norwegian IMM Plans (n 2), at p. 136 (referring to areas opened for petroleum exploration as per the award of licenses for the production of oil and gas for 2019) and at pp. 134 and 137 (indicating where areas will be opened for renewable energy production). Beyond the IMM plans, sectoral instruments exist that facilitate increased use, for example, Act No. 7 of 2019 on Mineral Activities on the Continental Shelf.

${ }^{74}$ Ibid., at pp. 131, 138.

75 North Sea IMM Plan (n 2), at p. 7.
} 
and harvesting of the area' ${ }^{76}$ The most recent IMM plans mention increased use of marine areas as a pressure, framing it as a consequence of adopting climate change mitigation measures: 'measures that shall give necessary emission reduction will increase the need to use the ocean areas' and 'when the ocean to an increasing extent is put to use to reduce the global emissions of climate change' ${ }^{77}$ In any event, the pressure is identified by the IMM plans, although economic concerns may have outweighed it, as, overall, the IMM plans primarily facilitate increased ocean use. ${ }^{78}$

With regards to providing relevant knowledge for the mitigation approach, the plans, including their scientific bases, do not discuss pressures (as opposed to their impact) on the global marine environment or how these pressures fall under Norwegian jurisdiction and influence. Such knowledge is likely rendered beyond the scope of the plans. Individually and in fragments, the plans do provide information on some individual pressures, such as fisheries (management strategies of unhealthy fish stocks, IUU fishing measures, port State and market State measures, and international cooperation). Beyond that, the plans focus on the pressures of activities operating locally, primarily food production, shipping, and petroleum exploration and exploitation. ${ }^{79}$

Although the IMM plans capture certain management responses to mitigate pressures, they do not attempt to address pressures systematically, or discuss common or root causes of pressures to suggest consistent measures. Such attempts are likely considered beyond their scope. Moreover, for the pressures that are identified, the plans adopt measures that are limited in scope. Consequently, while the IMM plans do identify some global pressures on the marine environment, they do not target them systematically, in terms of obtaining knowledge about the pressures and discussing the range of relevant Norwegian responses to them. Further, the IMM plans only capture a limited set of responses to some individual main pressures. Therefore, a mitigation approach is embedded in the plans only in fragments.

\section{The Impact Approach of the IMM Plans}

The IMM plans assess environmental status of the three marine areas, categorising some areas as particularly valuable and vulnerable, and some habitat types and species as vulnerable. ${ }^{80}$ All these types of categories reflect assessments of impact. However, the analysis focuses on the most elaborate of these, namely, vulnerability analysis. Although vulnerability analysis is part of a value and vulnerability analyses, only the vulnerability analysis is considered here, because value analysis appears to have objectives beyond environmental considerations. ${ }^{81}$

\footnotetext{
${ }^{76}$ Ibid., at p. 13.

${ }^{77}$ Norwegian IMM Plans (n 2), at pp. 64-65 (author's translation). If these statements are to be taken literally, some goals of the plans should be adjusted. Seemingly the goal is to increase the use (and thereby pressures) for the purpose of reducing climate change emissions. Such a strategy could benefit from a transparent discussion, including a thoroughly account of the how the reduction of emissions is to be achieved.

${ }^{78}$ See note 74.

${ }^{79}$ Professional Forum for Norwegian Sea Areas, Samlet påvirkning og miljøkonsekvenser: Faggrunnlag for revisjon av forvaltningsplanen for Barentshavet og havområdene utenfor Lofoten [Scientific basis of 2019 to the coming revision of the Integrated Plan for the Barents Sea], Report No. M-1299 (2019) (in Norwegian), at p. 29, available at https://www.miljodirektoratet.no/publikasjoner/2019/april-2019/samlet-pavirkning-ogmiljokonsekvenser/.

${ }^{80}$ As per all of the IMM plans (n 2). A new classification system of ecological status is being developed. See Norwegian IMM Plans (n 2), at p. 17.

81 O Irish, 'Identifying ecological hotspots in the United States and Norway: Turning ecosystem-based management into practice?' (2018) 98 Marine Policy 65-76, at pp. 68-71, identifies the steps of the process leading to a value and vulnerability analysis.
} 
Vulnerability in the IMM plans means 'sensitivity of the identified ecological areas in relation to the human activities fishing, shipping, petroleum, and external influences'. ${ }^{82}$ Thus, the vulnerability analysis targets the impacts of pressures on a certain area. Moreover, the delimitation or scale of a vulnerable area depends on how effects play out in marine ecosystems, natural systems and on single species, as expressed in the IMM plans. However, while the 2005 vulnerability analysis for the Barents Sea identified sixteen vulnerable areas or types of areas, ${ }^{83}$ only seven of these, including the four most vulnerable, were included in the plan. Why the remaining nine were not included in the plan is unknown to the author. ${ }^{84}$

The next question to consider is which management responses can be associated with the vulnerability analysis. The North Sea IMM Plan holds:

The designation of areas as particularly valuable and vulnerable does not have any direct effect in the form of restrictions on commercial activities, but indicates that these are areas where it is important to show special caution. To protect particularly valuable species and habitats, it is for example possible to use current legislation to make activities in such areas subject to special requirements. ${ }^{85}$

Therefore, vulnerable areas in the plans are not regarded as providing limitations to activities as such, but as indicators of special caution when undertaking activities. This understanding is also evident in practice, for example, in Norway's opening of new areas for petroleum production very close to and even inside vulnerable areas, ${ }^{86}$ and allowing fisheries activities in these areas ${ }^{87}$ Special caution is exercised in vulnerable areas for these activities, for example, the requirements banning exploratory drilling during certain time periods ${ }^{88}$ and environmental requirements applicable to certain activities. ${ }^{89}$ Thus, the management responses relevant for the impact approach relate to the capacity of being vulnerable. However, the IMM plans and their scientific bases provide no assessment of robustness to support whether these areas might tolerate existing activities (and new activities facilitated by the plans). A more reasoned and explicit robustness test would be particularly interesting for the North Sea and Skagerrak area in light of this area's unsatisfactory environmental status. Nonetheless, it is clear that an impact approach is embedded in the IMM plans.

\footnotetext{
${ }^{82}$ E Olsen, 'Identifying particularly valuable and vulnerable areas: A key tool for the integrated management plans for the Barents Sea and Norwegian Sea,' ICES CM 2008/E:14 (2008).

${ }^{83}$ Irish (n 81), at p. 70; M Knol, 'Mapping ocean governance: From ecological values to policy instrumentation' (2011) 54(7) Journal of Environmental Planning and Management 979-995, at p. 986.

${ }^{84}$ These analyses are under reassessment as per the Norwegian IMM Plans (n 2). Similar numbers for the Norwegian Sea and North Sea are unknown to the author.

${ }^{85}$ North Sea IMM Plan (n 2), at p. 41; similarly, Norwegian IMM Plans (n 2), at p. 7.

${ }^{86}$ E Johansen, 'Norway's integrated ocean management: A need for stronger protection of the environment?'32 Ocean Yearbook 239-263, at p. 261. Johansen shows how identification as a vulnerable area (and significant gaps in knowledge) does not hinder Norway from opening new areas for petroleum production very close to such an area. Since 2016, Norway has opened several areas for petroleum production within vulnerable areas. For 2019, see Ministry of Petroleum and Energy, 'TFO 2019: Stor interesse for norsk sokkel' Press Release No. 044/19 (4 September 2019) available at https://www.regjeringen.no/no/aktuelt/tfo-2019-stor-interesse-for-norsksokkel/id2667425/.

${ }^{87}$ See, for example, M-1299 (2019) (n 79).

${ }^{88}$ See, for example, Norwegian Sea IMM Update (n 2), at pp. 95-97.

${ }^{89} \mathrm{See}$, for example, the environmental requirements applicable to the 2019 award of licenses for the production of oil and gas. Norwegian Petroleum Directorate, 'TFO 2019: Miljø-, HMS-, og fiskerivilkår' available at https://www.npd.no/globalassets/1-npd/fakta/utvinningstillatelser/konsesjonsrunder-nor/tfo-2019/miljo-hms-ogfiskerivilkar-tfo-2019.pdf.
} 


\section{The Activities Approach of the IMM Plans}

The activities targeted by the IMM plans include the existing and expanding petroleum industry, ${ }^{90}$ shipping, and marine food production (including commercial fisheries) in the area. ${ }^{91}$ The plans capture a selection of environmental effects related to the petroleum industry, including emissions into the air and sea during production, noise from seismic surveys, and physical disturbances. Implicitly, other effects are beyond the scope of the IMM plans. Therefore, the IMM plans do not address potential negative effects of the related offshore supply and service industries, except to the extent that these are captured by shipping (note that coastal areas are excluded from the scope of the IMM plans). The plans expect petroleum production to increase in the coming years, ${ }^{92}$ yet do not state generally whether environmental effects are expected to increase or decrease.

The environmental effects of shipping in the areas captured by the IMM plans include emissions to air, the spread of non-native species via ballast water or biofouling, and noise. The IMM plans project an increase in shipping traffic of 41 per cent by $2040,{ }^{93}$ yet expect emissions of climate gases to decrease. ${ }^{94}$ The environmental effects of the marine food production industry captured by the plans include the removal of fish resulting from fisheries, bottom trawling, accidental by-catch, marine waste, and underwater noise. Moreover, the plans capture certain effects of the emerging offshore aquaculture industry. Finally, the plans briefly describe the tourism industry and emerging marine industries (including offshore wind power, marine bioprospecting, seabed mining, and carbon capture and storage) and some of their environmental effects..$^{95}$

The scale of these activities is, seemingly, those operating in or those that may operate in the Norwegian marine areas in the future. Certainly none of these industries exist and operate only in these waters, as they have port and land-based facilities and transport and export products elsewhere. Thus, all these industries have negative environmental effects throughout their life cycle that are implicitly beyond scope of the IMM plans. It should be noted, however, that at least some of these effects could be subject to other (sectoral) management regimes.

The knowledge in the scientific bases of the plans captures the petroleum, shipping, and commercial fisheries sectors, and the aforementioned environmental effects in Norwegian marine areas. ${ }^{96}$ Earlier versions of the IMM plans provided descriptions of the cumulative impact of the captured activities in each of the three marine areas. Whereas the most recent IMM plans highlight the importance of understanding the collective impact of all activities, the plans do not provide such a description, referring to the need for more knowledge and the need to develop methods to this end. ${ }^{97}$ This supports the argument made herein that assessing which exact pressure an impact stems from is easy in some instances, but is challenging if not impossible in most. ${ }^{98}$ Knowledge on each of the targeted activities, as well as on the impact of

\footnotetext{
${ }^{90}$ Norwegian IMM Plans (n 2), at p. 82.

${ }^{91}$ Ibid., at pp. 77, 68.

92 Ibid., at p. 82.

${ }^{93}$ Ibid., at p. 77.

${ }^{94}$ Ibid., at p. 81.

${ }^{95}$ Ibid., pp. 92-99.

${ }^{96}$ See note 58.

${ }^{97}$ Norwegian IMM Plans (n 2), at p. 55. Interestingly, section 10 of the Act No. 100 relating to the Management of Biological, Geological and Landscape Diversity of 19 June 2009 imposes an obligation on authorities to take into account the total load upon an ecosystem when considering one pressure on an ecosystem. Yet, as set out in section 2 of this Act, this obligation only applies 'as appropriate' (author's translation: 'så langt de passer') to the continental shelf and exclusive economic zone of Norway.

${ }^{98}$ Halpern et al. (2008) (n 34).
} 
climate change and long-range transport of pollution on the Norwegian marine areas, is nonetheless included in the plans. ${ }^{99}$

The next question to consider is the extent to which the IMM plans include management responses that target the reduction of environmental effects within the confined scope and scale of the activities approach. Management responses that call for the relocation or restriction of activities for environmental reasons include the designation of certain areas as vulnerable (and valuable) and the proposed establishment of marine protected areas. ${ }^{100}$ Another concrete management response includes the geographical constraints on the expansion of the petroleum activities. Whereas the plans facilitate the expansion of petroleum exploration and exploitation, only the constraints are deemed relevant for this environmentally focused analysis. (This fact illustrates how an activities approach increases negative environmental effects simply by facilitating an increase in activities.)

Another management response of the plans is the ambition to halve greenhouse gas emissions from national marine transport and fisheries by $2030 .{ }^{101} \mathrm{~A}$ framework for offshore aquaculture within an environmentally sustainable framework will be developed. ${ }^{102}$ The plans state that in opening areas and determining conditions for offshore renewable energy production, further knowledge on seabirds will be appreciated. ${ }^{103}$ Finally, the plans call for working towards a tightening of the ship safety regime and looking into the possibility of limiting the extent of cruise tourism around Svalbard. ${ }^{104}$

Beyond the aforementioned area-based management responses, responses are few, and many are vague. ${ }^{105}$ Yet, many relevant and important responses exist in Norwegian sectoral and cross-sectoral regulations, such as harvesting rules for fisheries and emissions regulations for all sectors. The plans do not make clear why some are included while others are not. The plans seemingly only capture new responses applicable to these marine areas. Where the plans include management responses, alternatives are not openly discussed, making it difficult to evaluate whether these responses take appropriate account of environmental concerns.

The IMM plans identify some of the environmental effects of petroleum activities, fisheries, and maritime transportation, while disregarding other negative effects of the included activities as likely beyond their scope. The knowledge in the scientific bases of the plans captures these sectors and considers their selected environmental effects. The plans include some relevant responses. Consequently, an activities approach is embedded in the IMM plans.

As noted above, the activities approach alone - even if applied by all States - will not lead to long-term conservation and protection of the marine environment. The activities approach, as embraced by certain statements in the IMM plans, in contrast, seemingly considers that such an approach will contribute to conservation and protection of the marine environment. For example, " $[\mathrm{t}]$ he management plans ... manage the use of the ocean so that ecosystems maintain their natural functioning and deliver ecosystem services' ${ }^{106}$ and '[i]n marine habitats that are particularly important for the structure, functioning and productivity of ecosystems, activities will be conducted in such a way that all ecological functions are maintained.' 107

\footnotetext{
${ }^{99}$ Further, the factual base for the Barents Sea provides an assessment of combined effects per ecosystem component. See M-1299 (2019) (n 79).

${ }^{100}$ Norwegian IMM Plans (n 2), at p. 138.

${ }^{101}$ Ibid., at p. 130.

102 Ibid., at p. 131.

103 Ibid., at p 137.

${ }^{104}$ Ibid.

105 As discussed above, obtaining information is not considered a response under the activities approach.

${ }^{106}$ Norwegian IMM Plans (n 2), at p. 12.

${ }^{107} \mathrm{Ibid}$., at p. 15. Yet, at p. 54 it is stated that there is uncertainty as to how activities within a defined (valuable and vulnerable) area affects the ecology and biodiversity of that area.
} 
Regardless of how strict the activities captured by the IMM plans are managed (even if they were banned), management of these activities alone cannot ensure that ecological functions are maintained. Other pressures on these marine areas, such as climate change and long-range transported pollution, would and will hamper management attempts unless such pressures are concurrently mitigated by relevant management regimes. Norway is not alone in designing integrated marine policies that promise more than they contribute to. The European Union Marine Spatial Planning Directive takes a similar approach by targeting marine activities in a confined marine area, yet aims for the preservation, protection and improvement of the marine environment. ${ }^{108}$ By capturing only certain marine activities, in other words a selection of pressures that arguably does not reflect fundamental, main or necessary pressures (for example, as aligned with the IPBES list or WOA1 taxonomy of pressures), but those relevant for a more limited purpose, the directive cannot possibly contribute to long-term protection and conservation of the marine environment as per the mitigation approach.

\section{Discussion and Concluding Remarks}

The IMM plans have collected and connected information on marine activities and some management efforts to preserve Norwegian marine areas based on sectoral and topical policies, plans, and management efforts. The overview they provide has made evaluation of different approaches to marine environmental protection possible. Now the time has come to clarify and refine the environmental approaches captured by the IMM plans.

Based on this analysis of the three approaches, the IMM plans take a mitigation approach only in fragments. The plans do refer to a set of main human pressures on the marine environment, but they do not link these with relevant management responses within the jurisdictional capacities of Norway (and the more limited scope of the plans). The plans could further consider the pressures jointly in order to address them systematically and target any common root causes of these pressures. Yet, it must be reiterated that Norwegian environmental efforts relevant to the mitigation approach exist beyond those captured by the IMM plans. Seemingly, the plans have deemed these efforts as beyond their scope.

The impact approach is vested in the IMM plans in terms of, for example, vulnerability analysis. The knowledge sought under this approach supports vulnerability, unlike robustness. The implied robustness of the remaining marine areas, in support of existing and expanding activities, could benefit from a transparent and adequate explanation.

The activities approach outlined here is embedded in the IMM plans. They embrace some environmental effects of a selection of activities, primarily petroleum production and fisheries. Although some restrictions are imposed on these activities, contrary to statements in the IMM plans, these responses alone cannot maintain ecological functions. Rather, they reduce some environmental harm or result in some environmental improvement. To avoid potential misconceptions by politicians, managers and stakeholders, no aims beyond those possibly achievable by the activities approach should be included in the plans. Designing integrated marine policies that aim for more than they can possibly accomplish is not unique to Norway. The EU Marine Spatial Planning Directive takes a similar approach by targeting marine

\footnotetext{
${ }^{108}$ Directive 2014/89/EU of the European Parliament and of the Council of 23 July 2014 establishing a framework for maritime spatial planning, OJ L 257 (28 August 2014), Articles 5 (2). Similarly, Article 1 of the Directive 2008/56/EC of the European Parliament and of the Council of 17 June 2008 establishing a framework for community action in the field of marine environmental policy (Marine Strategy Framework Directive), OJ L 164 (25 June 2008) calls for Member States to adopt marine strategies (programmes of measures) to achieve or maintain good environmental status of the marine environment.
} 
activities in a confined marine area, yet aims for objectives beyond those possibly achievable by this approach.

The IMM plans capture the impact and activities approaches, but capture the mitigation approach only in a fragmented way. As per the IMM plans, the main pressures on Norwegian marine areas at large are those threatening the global marine environment, meaning that the contribution of Norway to the conservation and protection of the marine environment would be relatively small, as Norway is but one of 200 sovereign States. It must be highlighted that Norway is a major contributor to some of these global pressures. ${ }^{109}$ However, the IMM plans do not target pressures resulting from Norway or Norwegian citizens or activities generally, only some of the effects of a selection of activities. Although through their approaches the plans facilitate some reduction of environmental harm or improvement in the environment from these selected activities, their overall contribution to the protection of the marine environment is limited, if not negative. By facilitating an increase in activities, the IMM plans likely lead to an increase of negative effects on the marine environment. The IMM plans should clarify the environmental objectives they aim for and the limited contribution they make to marine environmental protection arising from their limited scope. ${ }^{110}$ In any event, the plans and the plan-making procedures provide knowledge on the status and trends of national marine ecosystems that could and should be important premises of management. The activities approach is further demanded by the integration principle. ${ }^{111}$

The IMM plans aim for a broad set of objectives beyond that of protecting the environment. In light of the problem analysis and the three approaches discussed above, this author questions whether it is not only the trade-off against other objectives that has led to the limited environmental contribution, but also the scope and approach, of the plans. For example, regulatory efforts to mitigate global pressures exist, yet these are not recognised by the plans.

Could the IMM plans rightfully be issued in the name of ecosystem management given their limited environmental contribution? Many versions of the ecosystem approach ${ }^{112}$ capture all or one of the three approaches discussed here. It illustrates how such approaches could capture both net-negative contributions and small contributions to the environment in terms of the activities approach and the more considerable contributions of the mitigation approach. Both conceptualisation and management of the marine environment could benefit from refinement with regard to these differences. The diverging implications outlined in these three approaches calls for cautiousness in combining them. Otherwise, holistic ambitions, whether in the name of marine ecosystem governance, integrated management or both, may easily miss their target or aim for more than they can possibly accomplish.

Environmental ambitions (including that of this article) can be full of pitfalls, even following a problem analysis, especially if the problem analysis is not explicit. Norway is not alone in having environmental ambitions. The IMM plans blend ambitions across the three

\footnotetext{
${ }^{109}$ For example, with regard to per capita carbon dioxide emissions, Norway ranks number 8 in Europe and number 29 in the world. Gapminder, 2017 figures (the most recent figure available in February 2021).

110 Johansen (n 86), at p. 262, notes the IMM plans otherwise '[r]isk being used to legitimize the process as integrated and well-balanced'.

${ }^{111}$ CBD (n 9), Article 6(b)

112 See, for example, D Vousden, 'Large marine ecosystems and associated new approaches to regional, transboundary and 'high seas" management' in R Rayfuse (ed.), Research Handbook on International Marine Environmental Law (Edward Elgar, Cheltenham, 2015) 385-410; D Langlet and R Rayfuse (eds), The Ecosystem Approach in Ocean Planning and Governance: Perspectives from Europe and Beyond (Brill, Leiden, 2019); E Domínguez-Tejo et al., 'Marine spatial planning advancing the ecosystem-based approach to coastal zone management: A review' (2016) 72 Marine Policy 115-130; V De Lucia, The 'Ecosystem Approach' in International Environmental Law : Genealogy and Biopolitics (Routledge, Abingdon, 2019); P Singh and A Jaeckel, 'Future prospects of marine environmental governance' in M Salomon and M Till (eds), Handbook on Marine Environment Protection : Science, Impacts and Sustainable Management (Springer International Publishing, Cham, 2018) 637-657.
} 
approaches outlined here with a management scope that is only consistent with parts of two of these approaches. The case of Norway offers an example of an integrated marine policy that is a ripe for remaking. Integrated marine policies may provide local ecological assessments, give guidance on future status trends, and be an instrument for applying the integration principle on combined effects (to the extent possible). These aspects may be useful premises for activities planning. However, mitigation is perhaps too big a topic, too demanding in scope (with regard to prioritisation between national interests) and too different from marine activities planning to be included in such policies. If this is the case, integrated marine policies will never lead to long-term conservation and protection of the marine environment, but will maintain their relevance for more restricted environmental objectives. 